\title{
Variation of the defence mechanisms in two groups of mussels, Mytilus galloprovincialis Lmk. Seasonal and environmental effects - preliminary results
}

\author{
M.M. Santarem, A.J. Figueras, J.A.F. Robledo and J.R. Caldas \\ Instituto de Investigaciones Marinas Vigo. Spain
}

Correspondence to: Dr. M.M. Santarem, Instituto de Investigaciones Marinas - CSIC, Eduardo Cabello, 6, 36208 Vigo, Spain.

\begin{abstract}
Santarem. M.M., Figueras. A.J., Robledo, I.A.F. and Caldas, J.R., 1992. Variation of the defence mechanisms in two groups of mussels, Myths galloprovincialis Lmk. Seasonal and environmental effects - preliminary results. Aquaculture, 107: 181-188.
\end{abstract}

Hemolymph parameters of mussels from two locations in the Ria de Vigo (N.W. Spain) were studied. Hemolymph proteins agglutinin levels, and the total number of hemocytes varied according to the season and the locality.

Biochemical constituents of the hemolymph of bivalves play a significant role in host defense. Changes have been described in serum components of oysters (Crassostrea virginica Gmelin), such as agglutinins and lytic enzymes associated with seasonal and environmental variations, reproductive cycle and parasitism (Feng and Canzonier, 1970; Fisher and Newell, 1986; Ford, 1986; Chu and La Peyre, 1989). The present study is an attempt to better understand the physiological function of agglutinins, lysozyme, protein and their seasonal and environmental variations in the hemolymph of Mytilus galloprovincialis.

The biological material consists of mussels from the winter spawn placed at two sites in the Ria de Vigo (N.W. Spain) with different salinities: Limens, a near oceanic location and Domayo, a near estuarine habitat (Fig. 1). The experiments are being conducted over a l-year period and 20 mussels from each locality are collected quarterly. 
Hemolymph samples $(1 \mathrm{ml})$ are withdrawn with a syringe from the posterior adductor muscle. The total number of hemocytes from each mussel was determined in a Neubauer chamber. Then the hemolymph samples were centrifuged and the supernatant (cell-free hemolymph or serum) was collected. The assay of PLP (Polysterene Latex Particles, $0.605 \mu \mathrm{m}$ in diameter, Sigma, USA) agglutinin titre was performed with serum serially diluted in a 96-well plate. Activity was expressed as a reciprocal of the highest dilution causing agglutination of PLP. The lysozyme activity was performed spectrophotometrically according to the method of Shugar (1952). The unit of lysozyme activity (U) was defined as the amount of lysozyme that catalyzed a decrease in absorbance of $0.001 / \mathrm{min}$, at $\mathrm{pH} 6.24$ and at $22^{\circ} \mathrm{C}$, using a suspension of Micrococcus lysodeikticus as substrate. The total hemolymph protein was measured by the method of Lowry et al. (1951) using serum albumin as a standard.

The variations of different hemolymph parameters in the two mussel groups are reported. No significant statistical difference $(P>0.05)$ was observed (Table 1$)$ in the mean values of different hemolymph parameters among mussels from Liméns and Domayo in the April samples. However, in the July samples a significant statistical difference in the mean values $(\mathrm{P}<\mathrm{O} .05)$ of protein concentration, agglutinin titre and number of blood cells was detected between mussels from Limens and Domayo. No significant difference $(\mathrm{P}=\mathrm{O}$.645) was found in the lysozyme level between the July samples.

Studying the seasonal differences in the same biochemical parameters at each location (Table 2), there was a significant difference in the mean values of protein concentration and agglutinin titre but no significant difference in lysozyme level and number of cells in mussels from Liméns In contrast, the mussels of Domayo presented no significant difference in protein concentration and a significant difference in all the other hemolymph parameters.

Renwrantz and Stahmer (1983) reported that agglutinins from hemolymph of mussels promote the phagocytosis of yeast cells by Mytilus hemocytes. Hence, the high agglutinin titre found in the two locations during July, a period of high microorganism biomass in the water, could be an indication of physiological condition and of the activity of the defence system of the mussels. On other hand, the lysozyme levels in the 
same period, in Liméns, were not affected. This could indicate that lysozyme activity does not play a primary role in the defence mechanisms of mussels. Chu and La Peyre (1989) pointed out the possible link of hemolymph lysozyme and protein with the reproductive cycle. Our results could also suggest a possible connection of hemolymph lysozyme and mussel reproduction. However, for the moment, we can not come to final conclusions because these are preliminary results of a 1-year study and the results on gonadal development and pathological and environmental conditions are still being analyzed.

\section{ACKNOWLEDGMENT}

Maria Santarem has a fellowship from the "Ministerio de Educacion y Ciencia" of Spain.

\section{REFERENCES}

Chu, E.F. and La Peyre, J.F., 1989. Effect of environmental factors and parasitism on hemolymph lysozyme and protein of American oysters (Crassostrea virginica). J. Invert. Pathol., 54: 224-233.

Feng, S.Y. and Canzonier, W.J., 1970. Humoral responses in the American oyster (Crassostrea virginica) infected with Bucephalus sp. and Minchinia nelsoni. Am. Fish. Soc. Spec. Publ., 5: 497-510.

Fisher, WE. and Newell, R.I.E., 1986. Seasonal and environmental variations in proteins and carbohydrates levels in the hemolymph from American oyster (Crarsostrea virginica Gmelin). Comp. Biochem. Phvsiol., 85A: 365-372.

Ford, SE. 1986. Comparison of hemolymph proteins from resistant and susceptible oysters, Crassostrea virginica, exposed to the parasite Haplosporidium nelsoni (MSX). J. Invert. Pathol., 47: 283-294.

Lowry,O.H., Rosebrough, N.J., Farr, A.L. and Randall, R.J., 1951. Protein measurement with the Folin phenol reagent. J. Biol. Chem., 193: 265-275.

Renwrantz, L. and Stahmer, A., 1983. Opsonizing properties of an isolated hemolymph agglutinin and demonstration of lectin-like recognition molecules at the surface of hemocytes from Mytilus edulis. J. Comp. Physiol., 149: 535-546. 
Shugar. D., 1952. Measurement of lysozyne .activity and the ultraviolet inactivation of lysozyme. Biochem. Biophys. Acta, 8: 302-308. 
Fig. 1 Locations in the Ria de Vigo where the samples were taken.

Table 1 Comparison of hemolymph parameters in mussels from Limens and Domayo. Twenty mussels were sampled from each site. A T-test $(P<0.05)$ was used to compare the values of the two groups. Values are means with standard deviations in parentheses

Table 2 Comparison of hemolymph parameters in mussels in April and July. Twenty mussels were sampled from each site. A $T$-test $(P<0.05)$ was used to compare the values between the two groups. Values are means with standard deviations in parentheses 
Table 1

\begin{tabular}{lllllll}
\hline & April & \multicolumn{5}{c}{ July } \\
\cline { 2 - 6 } & Limens & Domayo & $P$ & Limens & Domayo & $P$ \\
\hline Protein & 0.498 & 0.649 & 0.126 & 1.265 & 0.485 & 0.000 \\
$(\mathrm{mg} / \mathrm{ml})$ & $(0.221)$ & $(0.372)$ & & $(0.579)$ & $(0.227)$ & \\
Agglutinin & 136.8 & 269.3 & 0.116 & 4416 & 2112 & 0.000 \\
titre & $(126.6)$ & $(345.6)$ & & $(1278)$ & $(1592)$ & \\
Lysozyme & 198.48 & 88.39 & 0.064 & 174.05 & 195.81 & 0.645 \\
$($ U/mg prot) & $(219.10)$ & $(63.49)$ & & $(156.67)$ & $(139.67)$ & \\
No. of cells & 3.390 & 3.620 & 0.111 & 2.505 & 1.458 & 0.042 \\
$(10 / m l)$ & $(2.742)$ & $(2.201)$ & & $(1.540)$ & $(1.607)$ & \\
\hline
\end{tabular}

Table 2

\begin{tabular}{lllllll}
\hline & Limens & \multicolumn{5}{c}{ Domayo } \\
\cline { 2 - 6 } & April & July & $P$ & April & July & $P$ \\
\hline Protein & 0.498 & 1.265 & 0.000 & 0.649 & 0.485 & 0.099 \\
$(\mathrm{mg} / \mathrm{ml})$ & $(0.221)$ & $(0.579)$ & & $(0.372)$ & $(0.227)$ & \\
Agglutinin & 136.8 & 4416 & 0.000 & 269.3 & 2112 & 0.000 \\
titre & $(126.6)$ & $(1278)$ & & $(345.6)$ & $(1592)$ & \\
Lysozyme & 188.48 & 174.05 & 0.813 & 88.39 & 195.81 & 0.004 \\
$($ U/mg prot) & $(219.10)$ & $(156.67)$ & & $(63.49)$ & $(139.67)$ & \\
No. of cells & 3.390 & 2.505 & 0.214 & 3.620 & 1.458 & 0.004 \\
$(10 / m l)$ & $(2.742)$ & $(1.540)$ & & $(2.201)$ & $(1.607)$ & \\
\hline
\end{tabular}

